\title{
Eco-labelling and product development: potentials and experiences
}

\author{
Frieder Rubik* and Dirk Scheer \\ Institute for Ecological Economy Research (IÖW) gGmbH, \\ Office Heidelberg, Bergstrasse 7, \\ D-69120 Heidelberg, Germany \\ E-mail: frieder.rubik@ioew.de \\ ${ }^{*}$ Corresponding author
}

\section{Fabio Iraldo}

IEFE - Institute for Environment and Energy Economics,

Bocconi University, Milan, Italy,

Scuola Superiore Sant'Anna, Pisa, Italy

E-mail: fabio.iraldo@unibocconi.it

\begin{abstract}
The last years promoted new policy instruments based on cooperation and aiming at a higher degree of voluntariness and self-regulation. Eco-labelling is a typical instrument applied in this context. Eco-labels award and promote environmentally superior goods and services and offer information on their quality and performance with respect to consumer health, resource consumption, and environmental impacts. We present an overview on the history and 'landscape' of eco-labels and explain objectives and mechanisms. Later, we examine potentials and experiences within business. In the following, an empirical view on the state, successes and failures of eco-labelling - primarily based on a meso- and macro-economic view - is presented. We close with consequences and challenges for strengthening eco-labelling.
\end{abstract}

Keywords: eco-labels; product development; product innovation.

Reference to this paper should be made as follows: Rubik, F., Scheer, D. and Iraldo, F. (2008) 'Eco-labelling and product development: potentials and experiences', Int. J. Product Development, Vol. 6, Nos. 3/4, pp.393-419.

Biographical notes: Frieder Rubik studied National Economics at the University of Heidelberg. He has worked for several environmental economics research institutes. Presently, he is a senior researcher at the Institute for Ecological Economy Research (IÖW), Berlin, Heidelberg, and Head of the Department of 'Ecological Product Policy'. His key publications deal with innovation, product information schemes/eco-labelling, Integrated Product Policy (IPP), and Life Cycle Assessment (LCA). Exemplary publications are "Governance of Integrated Product Policy. In search of Sustainable Production and Consumption" (Scheer, D. and Rubik, F., London, Greenleaf, 2006), "The future of eco-labelling" (Rubik, F. and Frankl, P., London, Greenleaf, 2005). 
Dirk Scheer studied Political Science and Literature in Heidelberg, Germany, and Seville, Spain. In 2001, he joined the Institute for Ecological Economy Research (IÖW) to work as a Research Associate in the IÖW department for 'Ecological Product Policy' at the Heidelberg office. He has carried out several inter- and trans-disciplinary research projects covering both conceptual and applied research issues. His areas of research interest are environmental governance, IPP, Sustainability Impact Assessment (SIA) and risk communication.

Fabio Iraldo graduated from Bocconi University in Economics and Social Disciplines. He holds a PhD from IUAV University in Venice. Presently he is an Associate Professor of Management at Sant' Anna Advanced School in Pisa and Research Director at IEFE - Institute for Energy and Environmental Economics at Bocconi. He is a Professor of Sustainability Marketing at the 3rd University of Rome. In 2006 he co-founded CESISP: the Inter-University Centre for Product Sustainability. Recently he acted as coordinator of a study for the revision of the EU ecolabel on behalf of the European Commission.

\section{Introduction}

Policy patterns are changing. Generally speaking, a transformation process towards new models of governance has begun promoting so-called new policy instruments based on cooperation and aiming at a higher degree of voluntariness and self-regulation. One typical instrument applied in this context is environmental labelling - eco-labelling. Eco-labels award and promote environmentally superior goods and services and offer information on their quality and performance with respect to consumer health, resource consumption, and environmental impacts. They provide a positive statement that identifies products and services as being less harmful to the environment than products in the same product category without a label. Eco-labelling differs fundamentally from the setting of minimum product standards or requirements in that it rewards environmental leadership. Eco-labels may cover several potential environmental impacts of products or services based on life-cycle considerations.

In this contribution, we concentrate on voluntary eco-labels, i.e., labels applied for reasons other than prescription by public regulation. Typical examples are the European eco-label, the Nordic White Swan or the German Blue Angel.

Section 2, The concept of eco-labelling, gives an overview of the history and 'landscape' of eco-labels. It provides information on countries using such a scheme, presents an important categorisation elaborated in this context, explains objectives and mechanisms and hints at the distinction between direct and indirect effects. Section 3, Eco-labelling and product development, refers to the potential and some experiences within business, i.e., on a micro-economic level. The following Section 4 Assessing the impacts presents an empirical view on the state, successes and failures of eco-labelling; primarily based on a meso- and macro-economic view. The final Section 5, Conclusions, deduces the consequences and challenges, both for business and policy, for strengthening eco-labelling. 


\section{The concept of eco-labelling}

Information transmission with regard to the environmental features of products and services has a history starting in the 1970 s of the last century. Their proliferation in the last three decades has included a great variety of different types and forms. One has the general impression that this area is, to a high degree - still - heterogeneous and fragmented.

Efforts have been made to classify existing labels according to mandatory/voluntary application status, and general characteristics of labels such as format, multi-stakeholder approach (see Rubik and Frankl, 2005, p.31ff.). An often applied categorisation is the one elaborated by the International Organisation of Standardisation (ISO) to structure environmental labelling. ISO developed a categorisation of voluntary labels into three types, namely ISO Types I-III.

- Type I: refers to criteria-based certification programmes and defines an ISO Type I labels:

"Voluntary, multiple criteria-based third party programme that awards a licence authorising the use of environmental labels on products. These indicate the overall environmental preferability of a product within a particular product category based on life cycle considerations. These labels provide qualitative environmental information." (ISO, 1999, p.1)

They are covered by ISO 14024 published in April 1999.

- Type II: describes environmental claims:

"Self-declared environmental claim made by manufacturers, importers, distributors, retailers, or anyone else likely to benefit from such a claim without independent third-party certification." (ISO, 2000, p.3)

They are covered by ISO 14021 published in 1999.

- Type III: applies to quantified product information that is based upon independent verification using present indices:

"providing quantified environmental data using predetermined parameters and, where relevant, additional environmental information." (ISO, 2007, p.9)

They are covered by the international standard 14025 published in 2007.

This categorisation provides a useful distinction between qualitative information, intending to deliver a clear and easy-to-interpret, condensed and aggregated (to one point) information, such as an eco-label, and a quantitative approach, which instructs customers on a broad set of categories needed by customers to enable them to interpret the information themselves.

The history of eco-labels - ISO-type I labels - began with the introduction of the German Blue Angel in 1978. The original objectives of the Blue Angel have been (UBA, 1990 as quoted in EPA, 1998) to guide the consumer in purchasing quality products with fewer adverse environmental impacts, to encourage manufacturers to develop and supply environmentally sound products, and to use it as a market-oriented instrument of environmental policy. The majority of similar national eco-labelling schemes emerged during the late 1980s and 1990s. At the supra-national level, two schemes exist. The EU-Flower was introduced in 1992. It had a major regulation 
revision in 2000 and will probably receive another revision in 2007-2008. The Nordic White Swan encompasses Denmark, Finland, Iceland, Norway and Sweden. At the regional level, one scheme has also been introduced; namely, the Catalan 'Distintiu', officially created by the Catalan Government in 1994. Eco-labels are not restricted to OECD-countries. Emerging economies like China and India have also introduced a label, but with modest positive experiences so far. Asian 'tiger' and 'panther' countries - except Malaysia - have also introduced a scheme.

Table 1 presents an overview of ISO-type I labelling schemes.

Table 1 Countries with ISO-type I eco-labels

\begin{tabular}{lll}
\hline $\begin{array}{l}\text { EU Member States with } \\
\text { national ISO type I }\end{array}$ & $\begin{array}{l}\text { Other states with national } \\
\text { ISO type I }\end{array}$ & $\begin{array}{l}\text { States with a supra-national } \\
\text { ISO type I }\end{array}$ \\
\hline Austria & Australia & $\begin{array}{l}\text { Nordic countries (Denmark, Finland, } \\
\text { Iceland, Norway, Sweden) } \\
\text { European Union (27 Member States) }\end{array}$ \\
Catalonia (Spain) & Brazil & \\
Czech Republic & Canada & \\
France & China & \\
Germany & Croatia & \\
Hungary & Hong Kong & \\
Lithuania & India & \\
Poland & Indonesia & \\
Slovak Republic & Israel & \\
Spain & Japan & \\
The Netherlands & Korea & \\
& New Zealand & \\
& Philippines & \\
& Singapore & \\
& Ukraine & \\
& Taiwan & \\
& Thailand & \\
& USA & \\
\hline
\end{tabular}

Source: Rubik and Frankl (2005, p.52); updated and supplemented

This wide-spread introduction of classical ISO type I schemes reflects a changing perspective in environmental policy towards more extensive use of new environmental policy tools. The ISO type I eco-label is a 'typical' example. Its main characteristics are:

- Voluntariness. In contrast to a mandatory and regulative approach, the application for an eco-label is up to business as provider of information and their consideration in purchasing decisions is up to consumers as customers. 
- Cooperation. The elaboration of the requirements and the final decision on their details is up to a pluralistic committee of which the members represent a multi-stakeholder climate e.g., environmental NGOs, consumer NGOs, business associations, retailers, policy. Here, a co-regulative approach becomes reality.

- Independence and reliability. The elaboration of the requirements has to be prepared by a cooperative approach and should be verified according to a prescribed procedure, of which, especially, third-party verification is a key element.

Altogether, eco-labelling could be regarded as a main instrument of a co-regulative environmental policy (see Scheer, 2006a, 2006b).

The history of eco-labelling has shown a continuous proliferation and an adoption of intentions and objectives. Although differences among applying countries exist, the main objectives are that both the supply and demand sides of market economies contribute to a final goal:

- $\quad$ Suppliers. Should get information - 'signals' - about requirements for a green product within a specific product group.

- Customers. Private consumers, public purchasers, commercial purchasers and retailers should become informed about green products available on the market within a specific product group.

- $\quad$ Net environmental benefits. Eco-labels are a market compatible efficient instrument reducing the transaction costs. But as a tool, eco-labelling is oriented towards one main objective; namely, generating net environmental benefits by substituting 'conventional' products with eco-labelled ones. This objective could be regarded as the final idea behind the system.

Eco-labels are based on pluralistic elaborated and verified requirements. The requirements could be interpreted as environmental 'hot spots', indicating what policy and society regard as 'minimum' voluntary standards for a green product within a specific product group. Its - voluntary - uptake by business could occur with or without changing the products. Without changing a product is obviously the case if a product already fulfils the requirements and neither its composition, nor materials contained, nor the production process must be changed. In this case, business could use an eco-label for marketing purposes and improve its competitiveness and unique selling position - that means business changes its sale strategy. The other case is if the product itself must be changed, either by modifying its composition or materials, or by changing its environmental features or by improving production processes. In this case, environmental innovation is stimulated. Product innovation and development processes are necessary to fulfil requirements and to award environmentally superior products.

There is another aspect to be considered more explicitly. The voluntary character of eco-labels allows business to choose to apply them or not. Companies applying an eco-label to their products intend to increase market share and to substitute environmentally less benign 'conventional' products with the eco-labelled ones. Other market competitors might be influenced by an eco-label without asking or applying for it. Such eco-labels could inform manufacturers about environmental 'hot spots' and constitute 'crash barriers' - stimulating, thereby, environmentally more benign product innovations. 
Looking towards customers, an eco-label intends to deal with the information gap. Under normal circumstances, information on environmental features delivered to customers cannot be judged to be valid; neither prior to, nor after, their purchase. In order to cope with asymmetric information, customers need external support for experience and credence of goods. Eco-labels claim to fill the information gap which so-called 'credence goods' leave behind, providing information transmission. Justifying this information requires testing those products to make the environmental performance obvious - a procedure not feasible due to high transaction costs. Eco-labels, therefore, aim to establish a reliable and trustworthy information system on product features. They are based on the belief in the rational behaviour of target groups and the influence on decision-making. Since customers are not able to judge as valid the environmental information by itself, they require information resources that they can trust. Scrutinising the validity of environmental information results in scrutinising the validity of the information resource; that is the procedure through which this information is generated. It becomes clear that by establishing eco-labels, consumers become able to judge the reliability of environmental information content; namely, through the reliability of third-party information schemes. Customers will get clear information about environmentally superior products.

Customers could consider an eco-label within their decision-making procedures or they could ignore it. Considering an eco-label could imply that eco-labelled products are substituted for those not labelled - thereby changing markets. Besides that, an eco-label could instruct customers on environmental 'hot spots' and increase their general awareness. Use of an eco-labelled product could also contribute to a change in consumption patterns.

Therefore, it is wise not only to look for the visible - the direct - impacts of an eco-label, but also for the hard-to-follow indirect possibilities, by informal application without formal application. It demonstrates that eco-labelling impacts are more complex and that the paths toward environmental benefits have to take into account two different, but also complementary, types of environmental benefits:

- Direct environmental benefits ('performance') meaning environmental improvements attained through the practised application of eco-labelling on products and services

- Indirect environmental benefits meaning environmentally positive impacts induced by eco-labelling schemes on surrounding policy, businesses and society (e.g., criteria as an informal 'standard', the eco-labelling multi-stakeholder approach as an initiator for cooperative action etc.).

This distinction is important for considering the opportunities of eco-labelling within product development and innovation processes, see Section 3.

Figure 1 illustrates the dynamic impact chain of an eco-label. It shows also that it is embedded in a set of contextual aspects, namely, a framework context (i.e., set of environmental policy tools), a technology context (i.e., technology innovation), a market context (i.e., competitors, decision situations etc.) and a business context (i.e., business short and long-term strategies). 
Figure 1 The dynamic impact chain of eco-labels

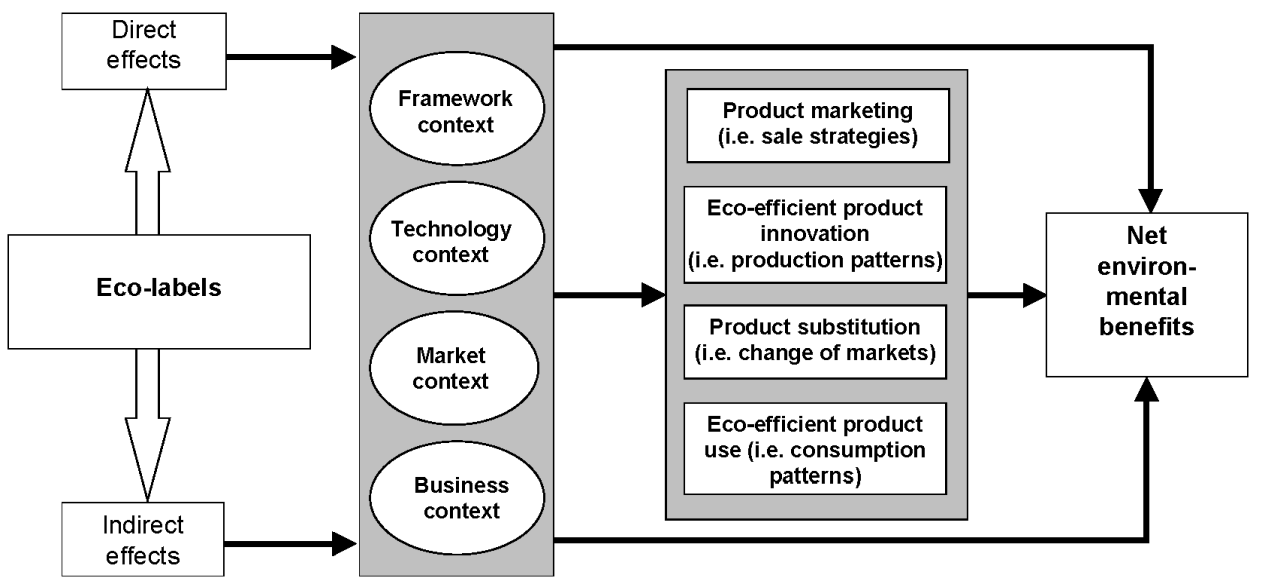

Source: Rubik and Frankl (2005, p.239), updated and supplemented

\section{Eco-labelling and product development}

As elaborated above, eco-labels could play a potential role in influencing and supporting the development of new and innovative products, conceived and designed to include concerns for the environment. Eco-labels could stimulate companies in their product development process and influence the range of products offered in markets. In spite of this emerging trend, also reported in the literature (see Section 4), few empirical studies have dealt with the subject of changing manufacturers' product development strategies to adapt to existing or newly elaborated eco-labels, or to their requirements.

The key question for researchers and practitioners is: How can eco-labelling influence product development?

Provided that one of the primary aims of new product development is to understand what makes product fail or succeed and to explore the critical role of product advantages in market acceptance and commercial success (Berchicci and Bodewes, 2005), there are many steps in a product development process that theoretically can benefit from the existence of an eco-labelling scheme (belonging to one of the typologies indicated in the first paragraph):

- the 'market intelligence', to identify the potential environment-oriented demand for the product and for its characteristics

- the role of eco-labels to foster 'demand-pull' innovation patterns and to improve and promote cooperation within the supply chain

- the use of the eco-label requirements and criteria as benchmarks and 'best practice' in product positioning and design

- the use of eco-label requirements and criteria to support compliance with product-related environmental standards. 
In the following section of this Section 3, we analyse the dynamics by which the existence of an eco-label, and the availability of the relevant environmental criteria, can play a role in supporting new product development.

\subsection{Use of the data on eco-label diffusion as an estimate for 'market intelligence'}

'Market intelligence' provides crucial inputs to the product development process, by making information and data available for the manufacturer on some key aspects, such as:

- consumer expectations and preferences

- level of acceptance by consumers of environmental performance

- market share of existing 'eco-friendly' competitors, etc.

First of all, companies can use the data on eco-labelled products to get information from the market and identify market opportunities for new product development. For many product categories, in fact, the only reliable data on the diffusion of green products in the market are the number of eco-labelled products and their market shares. By using data on the European eco-label, for instance, a producer might focus on the success that green products in its category have on the market. This is the best way to provide indications to designers about how to satisfy a potential or actual demand for environmental performance by the market. Besides the fact that the market performance of eco-labelled products is heterogeneous in different sectors and countries (see next paragraph), what is important is that a marketing manager of a company can use the relevant data as reliable indirect indicators of the 'environmental' demand to which a newly developed product should be able to respond. In the case of paints and varnishes; for example, a manufacturer could use the eco-label market shares reported in Table 2 as an indication of consumer sensitivity, country-related specificities, penetrability of the market, potential sale outcome, etc. This data is fundamental for effectively defining and developing a product 'concept' tailored to the needs of target-segments of the market.

Table 2 Market intelligence through surveys on eco-label diffusion

\begin{tabular}{lccccccc}
\hline $\begin{array}{l}\text { Eco-labelled paints and } \\
\text { varnishes (year 1999) }\end{array}$ & Sweden & Finland & $\begin{array}{c}\text { United } \\
\text { Kingdom }\end{array}$ & Portugal & Spain & France & $\begin{array}{c}\text { European } \\
\text { Union (total) }\end{array}$ \\
\hline $\begin{array}{l}\text { Sales value } \\
\text { (in Millions } € \text { ) }\end{array}$ & 263 & 150 & 1,311 & 188 & 506 & 1,300 & 3,618 \\
Market share (\%) & 15 & 1.6 & 0.13 & 0.12 & 0.04 & 0.002 & 1.23 \\
\hline
\end{tabular}

Source: IEFE et al. (2006, p.117)

\subsection{Eco-labelling as a mutual influence and cooperation opportunity in the supply chain}

Another important aspect related to eco-labelling is the involvement of customers and suppliers. This is regarded as a crucial factor in promoting the adoption of environment-oriented new product development, according to Pujari et al. (2003). 
Customers and suppliers play a key role in stimulating and providing the incentive for the inclusion of environmental concerns in product innovation. Some of the most interesting dynamics of cross-fertilisation between suppliers and customers have taken place thanks to the adoption of eco-labels. The potential influence within the chain is confirmed by OECD which states

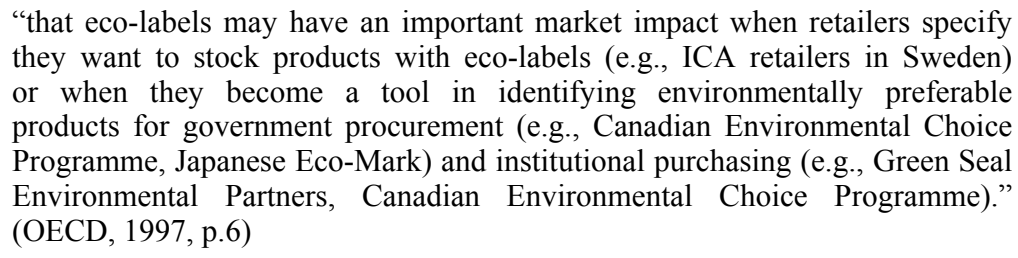

Iraldo (2000) shows that the large majority of retailers involved in an empirical study use the eco-label as an effective and useful assessment tool for their suppliers, in order to select them for their vendor-lists. This produced an increase in the development of eco-friendly products that led Italy becoming the Member State in which the EU eco-label is most diffused.

Even more interestingly, the outcome of 'cross-fertilisation' is an attitude to promote cooperation between customers and suppliers (Foster and Green, 2000), especially if these are small companies (not used to investing resources in environment-oriented new product development on their own). Empirical evidence confirms that 'co-design' between large customers and supplier SMEs is frequently implemented when the impulse comes from the customers' need to have an eco-label on the supplied products (Carnimeo and Iraldo, 2000; Fuller, 1999).

IEFE et al. (2006) confirm that about $3 / 4$ of the companies participating in the European scheme (strongly) agreed that the eco-label has influenced their demands on suppliers; moreover, nearly $74 \%$ of the participants observed an influence on the information exchange with commercial clients.

Eco-label criteria can also become a key issue through the so-called 'greening' of public procurement. This is especially so if one considers the significant weight of public institutions in the purchase of products and services on the market. In order to have a clearer idea of the dimension and importance in terms of market share of public purchases, it might be enough to consider that they represent an average of $17 \%$ of the Gross Domestic Product (GDP) in the EU. More and more public administrations today are inducing the use of eco-friendly criteria in product development by applying environmental standards linked to the eco-label criteria for their purchase orders. In this way, they can sensitise and stimulate suppliers. According to IEFE et al. (2006), the interest in public tenders (and the possibility of having a facilitated access) has proved to be one of the highest motivations to develop an eco-friendly product for the interviewed companies, both participating and non-participating, in the EU eco-labelling scheme.

Recently, the Take 5 Consortium (Bouwer et al., 2005) emphasised the degree of diffusion of green public procurement in public administrations throughout the EU. As it clearly shows in Figure 2, in most Member States the majority of central and local authorities (and other public administrations) have already adopted environmental criteria in public tenders, the EU average being $67 \%$. 
Figure 2 Percentage of public institutions that are adopting GPP (see online version for colours)

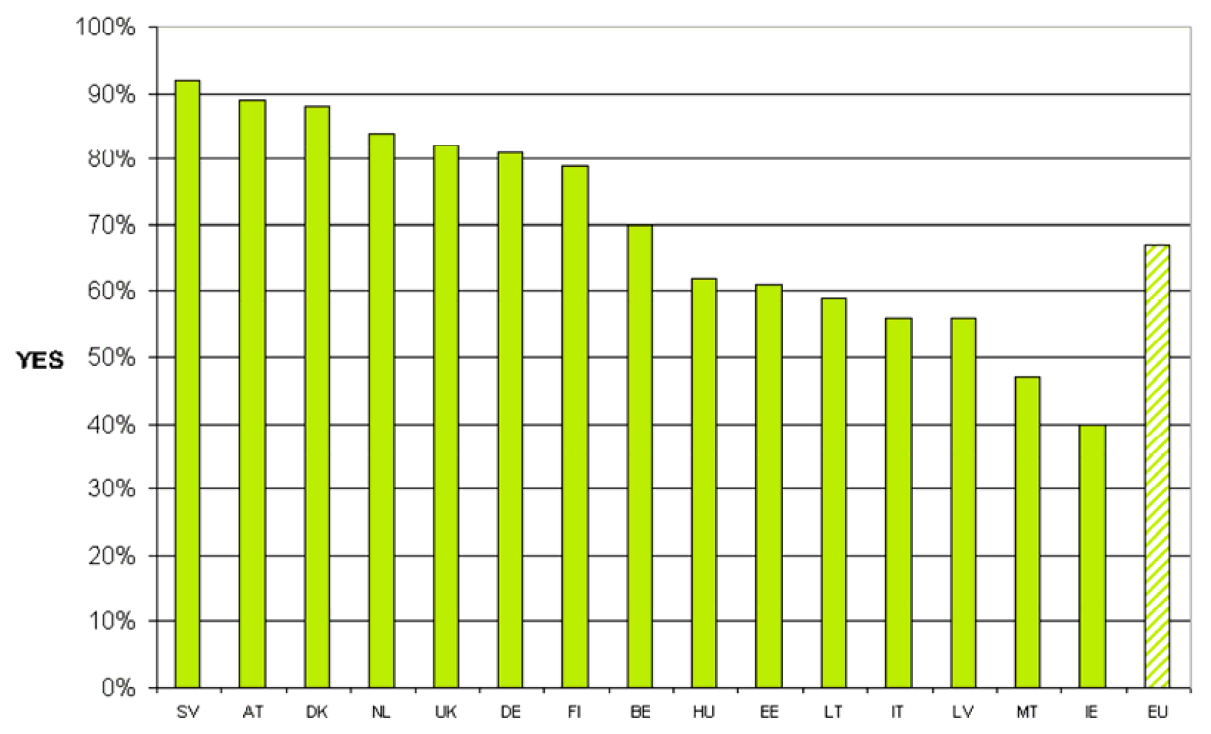

Source: Bouwer et al. $(2005, \mathrm{p} .43)$

\subsection{The use of eco-label in positioning and designing the product}

Eco-labels could be applied within the design process of a product and its later positioning on the market. We will stress these aspects in the following.

\subsubsection{Do designers need eco-labels?}

As the literature emphasises (Bennet and James, 1999; Tukker et al., 2000; Pujari et al., 2003), in order to effectively perform an environment-oriented design process, a designer needs to have clear indications on:

- What are the most important environmental impacts in a product life-cycle

- What are the achievable performances

- Most important of all, what are the ways in which these can be pursued (e.g., adoption of best available technologies, raw material substitution, recovery measures, etc.).

A large part of the literature identifies poor data quality and availability on environmental impacts and the high costs connected with the retrieval of useful environmental information as the two main barriers for diffusion of an environment-oriented new product development (see Gloria et al., 1995). EHS Gestione (2006) confirmed this. They hinted that designers are increasingly carrying out environmental assessment prior to the design of a new product. In particular, designers are interested in performing preventative assessment of the material and the components' environmental impact. Even if innovative tools such as Life Cycle Design (LCD) or, more generally, eco-design are still not very diffused, environmental concerns are increasingly affecting the choices of designers The 'demand' side is exerting pressure to take the impact on the 
environment into account within the design process. According to them, to further evaluate environmentally friendly alternatives, more information should be available to designers, especially on costs and performances of these innovative products and materials, so that they can be fully compared with traditional alternatives.

EHS Gestione (2006) identifies some relevant barriers to the adoption of environmental concerns in new product development and, in particular, in the design process. Quite interestingly, the lack of easy-to-use design tools and, especially, of usable data and information on environmental impact (e.g., database and guarantees) is considered crucial.

The most relevant barrier for designers is that, in most cases, the information on what are the best environmentally performing products and materials is not enough and, even when environmental information is available, this is not scientifically 'well grounded' and may result in confusion. The designers involved in the study agreed that the desired characteristics for an 'eco-friendly' product or material are practical only on the basis of reliable information and guarantees on the preferable alternative.

While, on one hand, the importance of environmental performance is widely agreed upon, on the other hand it is hard to define a common approach and useful tools to identify in a credible and non-controversial way what the 'eco-friendly' materials and products are. According to most designers, an 'eco-friendly' product or material has to be the result of a whole and pervasive assessment, taking into account all the different impacts from the beginning to the end of the life cycle. Any information available should, therefore, be based on a universally accepted standard for measuring the environmental impacts on objective and transparent criteria. Moreover, there is no doubt for designers that environmental performance should be guaranteed. More than $70 \%$ of the designers involved in the study believed that environmental certification is fundamental both to selection of materials and intermediate products, and as a reference for the design of a new product. Such guarantees must come from a respected and highly credible independent third party. Most of the designers are sceptical of environmental information which is provided directly by the suppliers.

As shown in Figure 3, the outcome of the study provides a positive answer to the initial question: the preferred form of certification by the designer are eco-labels, both of ISO-type I (31.3\% of the designers) and of type III (20.5\%), i.e., the quantitative oriented information. To obtain environmental information, $27.7 \%$ of the designers also strongly rely on results from direct testing on the product (or prototypes).

\subsubsection{How can the eco-label be used in product positioning and design?}

A relatively large number of companies report the incorporation of explicit environmental concerns in design. Some authors emphasise in their works the potential integration between the environmental dimension in some of the key product-related processes and activities like supply chain management (Bennet and James, 1999), R\&D (Tukker et al., 2000), marketing management (Fuller, 1999; Cramer 2000; Sullivan and Ehrenfeld, 1992), etc. But these encouraging indications refer to companies that take into consideration general environmental concerns. When we consider more operational design tools and 'in-depth' methodologies, the indications are far less positive. 
Figure 3 Product certifications preferred by designers

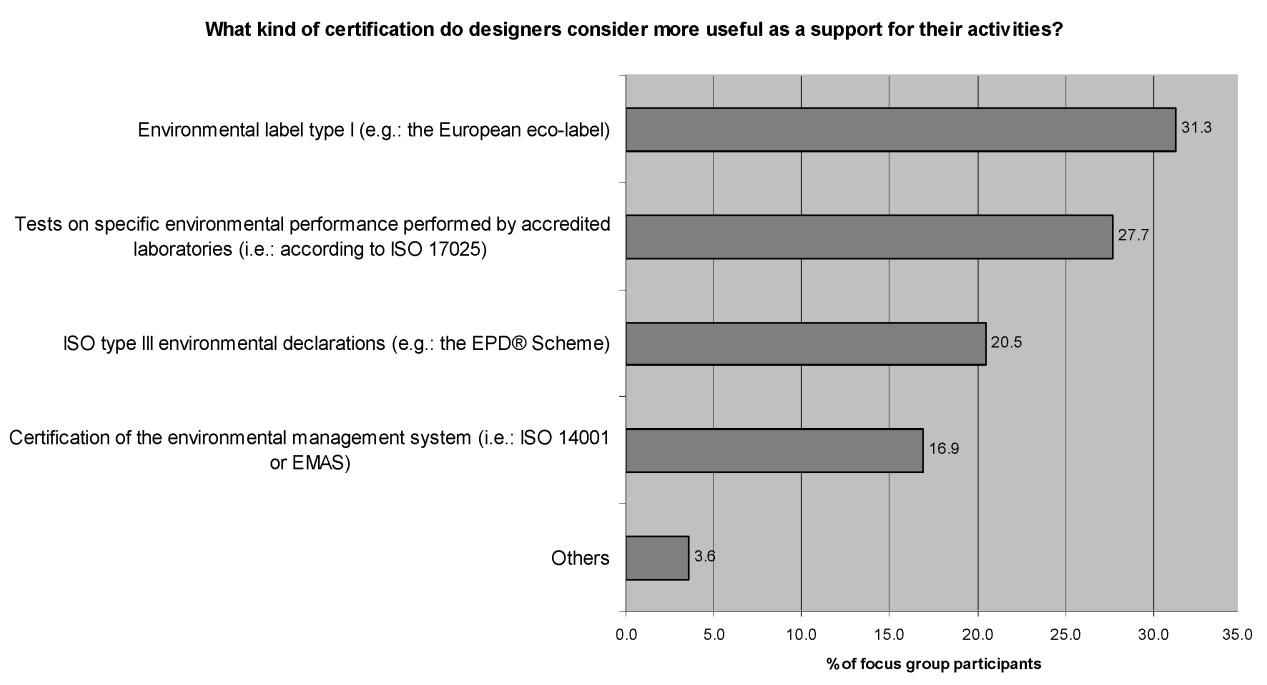

Source: EHS Gestione (2006)

As far as the diffusion of environmental concerns (and criteria) in new product development is concerned, there is a great lack of empirical data in the literature. Although many authors (e.g., Baldo, 2001; Carnimeo and Iraldo, 2000) report increasing adoption rates, many others are sceptical or even pessimistic, especially with reference to product-innovation processes.

One piece of interesting empirical evidence refers directly to the influence of the EU eco-label on the adopters' product-related environmental performance and innovation: IEFE et al. (2006) questioned actual participants of the EU-Flower as to their opinion of the label's influence on environmental performance. Nearly $2 / 3$ of them indicated that the objective of improving environmental performance was very or fairly important for their application for the Flower. Almost every second interviewee indicated that the Flower had some effect on the environmental performance of the product in the areas of air and water emissions, waster/recycling and water/material use; improvements with regard to accidents/spills were rare and for noise/smell observed by $1 / 4$ of interviewees (cf. Table 3).

Applying for the Flower means also to document the environmental performance of the product in question. IEFE et al. (2006) asked participants and non-participants of the EU-Flower in this context for environmental targets of their products. About half of the participating and non-participating companies declared that they set targets for environmental improvements of their products for all or most areas. Each fifth participant and each fourth non-participant declared not to do it at all. Forty one percentage of the participants and $55 \%$ of the non-participants declared, that they regularly measured environmental performance. It is astonishing that about $1 / 3$ of companies participating in the EU eco-label indicated that they did not measure at all. $42 \%$ of the participants indicated that the Flower has contributed to the setting of environmental targets in all or most areas. 
Table 3 Rating effects of the European eco-label on environmental performance improvement in the product life cycle in some areas?

\begin{tabular}{lccc}
\hline Environmental topic & Yes $(\%)$ & No $(\%)$ & Don't know $(\%)$ \\
\hline Air emissions & 50 & 27 & 23 \\
Water emissions & 47 & 33 & 20 \\
Waste and recycling & 45 & 32 & 23 \\
Water and material use & 47 & 32 & 21 \\
Noise and smell & 26 & 41 & 33 \\
Accidents and spills & 2 & 48 & 43 \\
\hline
\end{tabular}

Original question: "How would you rate the effect of the eco-label on environmental performance improvement in the product life cycle in each of the following areas? (please estimate annual improvement as \% of total if possible)."

Source: IEFE et al. (2006, p.91f.)

How can an eco-label be used to favour and simplify the adoption of an environment-oriented approach in product development and design?

A preliminary and fundamental step for the effective design of a new product is the definition of its attributes. This holds true for products that are designed and developed with the aim of valorising their environmental performance.

The 'green positioning' of a product aims at identifying the main competing alternatives on the market, and characterising them as concerns for their environmental performance and competitive capabilities. In order to carry out this phase of the product development process, a producer needs to define and estimate some key-indicators for the different environmental and competitive variables that play an important role for the success of the product.

The effectiveness of the key-indicators strongly depends on the availability of benchmarks in terms of "good environmental performance" and of comparable data for competitor products. Among the environmental data that can be used for creating key-indicators are, for example, outcomes of LCAs, databases. Eco-labels can play a crucial role in this prospect. They can be a reliable, easily achievable and usable source of information on specific or 'average' performance relating to different kinds of products. This information can then be used to define benchmarks in the design of the new product's environmental attributes.

For example, in order to achieve a correct 'green positioning' a producer can, on the basis of key-indicators, draft a 'radar' map to compare the new product with the eco-label criteria and with the main competitors (in Figure 4 we propose a simulation using the kinds of criteria that are set for washing machines).

Besides providing support in positioning the product according to its key environmental performances, the eco-label can go even further and be useful for a producer in the 'core phase' of the development process: design.

As we mentioned above, to be effective, an environment-oriented design process has to rely on information relating to the most important environmental impacts in a product's life-cycle, the achievable performances and the modalities to pursue them. 
Figure 4 Benchmarking with eco-label criteria through a radar map (see online version for colours)

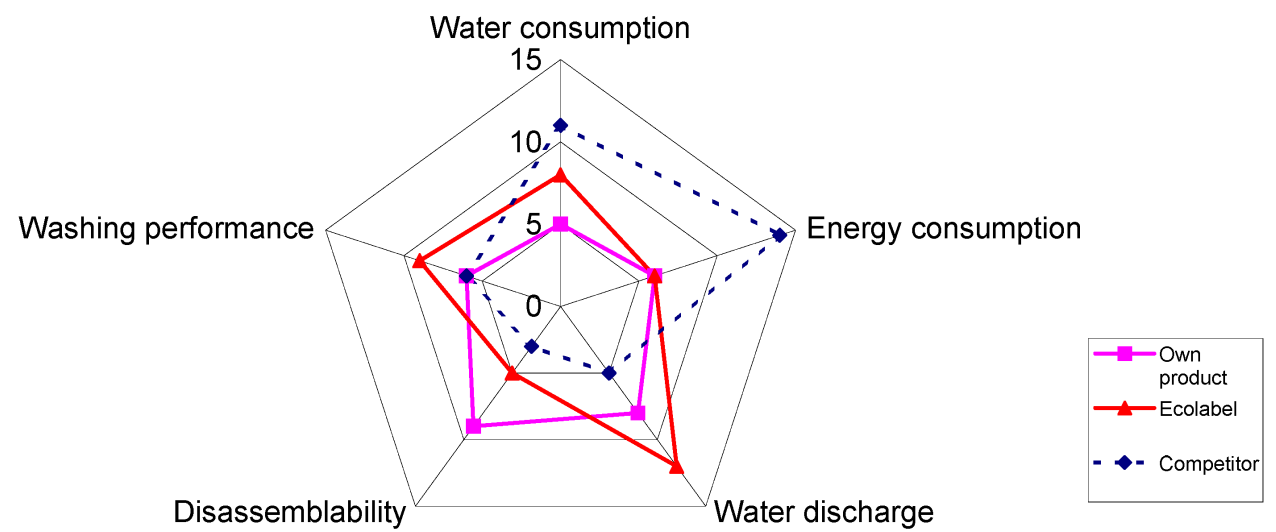

Source: EHS Gestione (2006)

The eco-label criteria are defined, expressed and enforced in such a way as to provide designers with implicit or explicit suggestions on all the aspects mentioned above. At a minimum, the criteria can be a useful benchmark for designers, showing them both the environmental impacts that should be taken into consideration when conceiving a new product, and the levels achieved by the supposedly 'top performing' product (even if, in many cases, eco-label criteria are based only on a virtual simulation of an ideal product that does not yet exist). We have to remember, in fact, that the type I eco-label criteria are developed and fixed according to the results of a LCA, and reference levels are fixed to guarantee that at least 5-30\% of the producers operating on the market are able to obtain certification. This approach enables designers to use the eco-label criteria as benchmarks for designing an 'eco-benign' product whose attributes and characteristics are widely agreed upon and accredited by European institutions.

In fewer cases, eco-label criteria are also able to propose to designers some 'best practices' as suggestions on how to improve the environmental performance of a product or a service.

An interesting case-study is the design of a new copy-paper product ('Ecocopia') by the Italian company Cartiera Verde Romanello (CVR), among the first producers to obtain the European eco-label. When defining the key features of this new product, the CVR designers did not have any information or data available on competitors to be used as benchmarks. So they took the criteria established by the three most diffused eco-labels in the EU as reference standards and worked on a complete reengineering that was able to achieve a relatively better environmental performance when compared to the three sets of criteria (See Table 4).

After interviewing companies which are not applying the European eco-label, IEFE et al. (2006) show that this benchmarking exercise is rather diffused among companies. Half of them performed this assessment in the past and were aware of the degree of compliance with the eco-label requirements. (Most of them indicated that between $80 \%$ and $95 \%$ of their products would fulfil them.) 
Table 4 Benchmarking on requirements of Cartiera Verde Romanello (CVR)

\begin{tabular}{lcccc}
\hline & $\begin{array}{c}\text { Ecocopia }(\text { product of } \\
\text { the CVR company) }\end{array}$ & EU ecolabel & Nordic Swan & Blue Angel \\
\hline $\mathrm{COD}(*)$ & $<0.75$ & $<1.25$ & $<2.0$ & N/A \\
$\mathrm{NO}_{\mathrm{X}}(*)$ & $<1.0$ & $<1.5$ & $<2.0$ & N/A \\
$\mathrm{S}\left({ }^{*}\right)$ & $<0.75$ & $<1.25$ & $<2.0$ & N/A \\
$\mathrm{CO}_{2}(\mathrm{~kg} / \mathrm{t})$ & $<650$ & $<1.000$ & $<1.000$ & N/A \\
$\mathrm{AO}_{\mathrm{X}}(\mathrm{kg} / \mathrm{t})$ & $<0.005$ & $<0.25$ & $<0.25$ & N/A \\
Energy consumption $(*)$ & 1.12 & $<1.5$ & $<1.75$ & N/A \\
Heat $(*)$ & 1.003 & $<1.5$ & $<1.75$ & N/A \\
Recycled fibres $(\%)$ & $100 \%$ & $100 \%$ & $>50 \%$ & $>95 \%$ \\
Chlorine & No & Forbidden & Forbidden & Forbidden \\
Residual Monomers $(\mathrm{ppm})$ & Not used & $<100$ & $<100$ & $<100$ \\
\hline
\end{tabular}

$(*)$ : All these criteria are expressed in 'Points' calculated according to EC rules.

N/A: Not applicable.

Source: Cartiera Verde Romanello, internal data, 2004

Finally, eco-labels can be a useful tool for designers also because they are able to provide indications of the way in which environmental performance can be effectively coupled with quality performance. In a design process, the environmental performance must be balanced by other considerations including cost, availability, technical feasibility and quality performance. According to Berchicci and Bodewes (2005) introducing environmental issues into new product development requires a trade-off between traditional product evaluation attributes and environmental ones and, consequently, there is a risk of choosing an environmental attribute that may conflict with market requirements. In this case, an eco-label can be a supportive tool. Let us consider the EU eco-label: The requirements and the criteria for the different product groups are conceived so as to guarantee that eco-labelled products, besides being 'eco-friendly', are able to satisfy high customer expectations as to quality and performance in use. For this very reason, the European eco-label includes amongst its requirements many quality performance standards that can be a guideline for designers.

\subsection{Eco-labels as a way to comply with standards on eco-design}

In coming years, environmental concerns will increasingly have to be taken in consideration by designers because of legal compliance. For some product categories, such as the Energy-using Products (EuPs), in fact, this will soon become a mandatory legal requirement. The European EuP-Directive (2005/32/EC) - better known as the Eco Design Directive - establishes that producers of EuPs adopt and implement technical specifications in the design phase, aimed at preventing and reducing the product environmental impact during the whole life-cycle. Detailed specifications will be set according to specific sub-categories (e.g., washing machines, refrigerators, heating systems, etc.) by way of implementation measures, to be defined by the European Commission in 2007. Only products that comply with the technical specifications will be 
allowed to use the 'CE' logo on the product and, therefore, to be commercialised in the EU internal market.

Once again, an eco-label, especially the European eco-label one, can support designers. They can refer to eco-label criteria for their design choices or, even more proactively, they can obtain this certification for their EuPs, anticipating the tasks that will be required by the Eco Design Directive. In its Article 9(3), the Directive states:

\footnotetext{
"EuPs which have been awarded the Community eco-label pursuant to Regulation (EC) No. 1980/2000 shall be presumed to comply with the Ecodesign requirements of the applicable implementing measure insofar as those requirements are met by the eco-label."
}

Moreover, the EU eco-label is de facto recognised as a 'harmonised standard' and, therefore, will be used by the EC policy-makers to set technical requirements for the design of eco-friendly EuPs, to be made mandatory by means of the foreseen implementation measures.

\section{Assessing the impacts: empirical evidence for direct and indirect benefits}

Successful eco-labelling activities rely on both market efficiency and environmental effectiveness. However, opinions differ on whether 'real world' eco-labels are able to do so. Cautious estimates find it difficult to tell how much eco-labelling has indeed contributed to reducing environmental stress (Yang, 1998, p.7). The difficulties of judging the environmental benefits and market efficiency are above all due to a lack of adequate parameters on how to measure what. Research on the environmental effectiveness of labelling programmes remains anecdotal (EPA, 1994; OECD, 1997; Neveling, 2000). Systematic research on quantitative and qualitative parameters indicating direct and indirect environmental benefits of eco-labelled products and services, therefore, is strongly needed.

However, in the following we give an overview on the empirical landscape of assessing the benefits of eco-labels.

\subsection{Direct effects: assessing the environmental performance}

The more eco-labelled products are sold and bought by consumers, the more they can 'substitute' for environmentally less benign products. Even if there has been considerable research in the field of eco-labels, there has clearly been a lack of assessing and evaluating direct effects systematically. An important indicator of successful market penetration is the market share of eco-labelled products in relation to all other products sold belonging to the same group (Rubik and Frankl, 2005, p.85). However, the OECD (1997, p.5) concludes that "in practice, data concerning the market impact of eco-labelled products is very difficult to obtain". In short: research on market shifts is rare (Frey et al., 1998, p.19).

\subsubsection{Anecdotal data on market share success and failure}

Data on the market diffusion of eco-labelled products exist for one or the other product group and eco-labelling scheme. According to the $\operatorname{OECD}(1997$, p.5) some scattered anecdotal evidence shows that sales have increased when an eco-label has been obtained. 
But patchwork data do not permit us to draw general conclusions for a positive or negative eco-label assessment. With regard to the European Flower, few examples could be found: Jordan et al. (2004) report a market share of paints with the EU-Flower about $0.1 \%$, above we presented in Table 2 a share of $1.23 \%$.

An OECD (1997) study of the market share for the German Blue-Angel concerning eco-labelled paints reported an increase in market share from $1 \%$ in 1981 to $60 \%$ in the do-it-yourself sector and $20 \%$ in the handicraft sector in 1995. An assessment for the Nordic White Swan, as reported by Rubik and Frankl (2005, p.86f), estimated the market shares for several product groups:

- "for printing paper, it was estimated that the share is about $70 \%$ in all Nordic countries (except for Iceland)

- $\quad$ regarding printed matter, the shares of eco-labelled products are higher in Sweden (about 70\%), being 40-70\% in Denmark and 10\% for Norway and Finland

- the highest market shares of eco-labelled laundry detergents are found in Sweden (70\%), followed by Norway (40-70\%) and Finland (10-40\%), whereas they are less than $10 \%$ in Denmark and Iceland

- for all-purpose cleaners, the shares are up to $40 \%$ in Sweden and Norway and between $10 \%$ and $40 \%$ in the other Nordic countries".

Considering the EU-Flower, we can use two secondary parameters relating to the absolute number of licenses for the use of the European eco-label and to the absolute number of applicants. Nowadays, 639 (July 2008) licenses for the use of the European eco-label have been granted for several hundred products. It is clear that the global EU market share, although not estimated, is still relatively small.

"This is far from the $5-10 \%$ or even $20-25 \%$ market share 'objective' being discussed in the EU Eco-label policy management scenario documents, and certainly far from the $30 \%$ potential identified in the EU Eco-label work plan." (Schiesser and Shinn, 2004, p.26)

What remains unclear is the market share of eco-labelled products against non-eco-labelled ones in a specific product group.

\subsubsection{Consumer awareness of eco-labels}

In the field of eco-labelling research, the most reliable data exists on consumer awareness of eco-labels. For both national and supranational schemes, several surveys on consumer awareness have been carried out. According to a survey resulting from a website questionnaire conducted by BEUC (2002), 38\% know the EU eco-label and 74\% did not know where to find products with the European eco-label.

In a comparative representative four-country survey Rubik and Frankl (2005, p.110) reported disappointing figures: $1 \%$ of German consumers, $1.7 \%$ of Norwegian, $0.4 \%$ of Italian and $1.2 \%$ of Spanish consumers knew the EU-Flower without getting any help. Their survey showed that national eco-labels are still the best known among consumers with $56.6 \%$ for the Blue Angel in Germany and a remarkable $70 \%$ for the White Swan in Norway. Additional country specific results are: 
- Austria. Leitner et al. (2004, p.7) reported recognition of the EU-Flower among Austrian consumer as 13\% from a representative survey of January 2004.

- Belgium. Rousseau (2004, p.15) found that $28 \%$ of the Belgian population knew the EU eco-label and that (once more) $28 \%$ of them possessed a correct perception of its role, i.e., $8 \%$ of the population.

- Italy. A periodical survey carried out in Italy (Demoskopea, 2003) showed that only $2.5 \%$ of interviewees knew the EU eco-label and, among them, only $40 \%$ was aware of its role and of the guarantees that it provides.

- Denmark. According to recent information, $89 \%$ of Danish consumers recognised the Swan whereas $65 \%$ recognised the EU eco-label. Only half of consumers that recognised the EU eco-label knew what it stood for.

- Finland. In Finland, the picture is a bit different: $86 \%$ of Finnish consumers had a spontaneous awareness of the Swan, but the qualified knowledge decreased significantly from $77 \%$ in 1998 to $39 \%$ in 2004 , because more and more consumers confuse the Swan with the 'Good from Finland'-label (which is also a styled Swan) and they say that the label means a domestic product or domestic production. Fifty seven percentage of Finnish consumers have a qualified knowledge of the EU eco-label (Taloustutkimus, 2004a, 2004b).

- Norway. In Norway, $87 \%$ of consumers have a qualified knowledge of the Swan whereas only $8 \%$ know the EU eco-label (Miljømerking, 2005).

- Sweden. The same picture goes for Sweden where $90 \%$ of consumers (Taloustutkimus, 2004b) have a qualified knowledge of the Swan and only $6 \%$ know what the EU eco-label stands for Kvistgaard Consults (2005, p.37).

\subsubsection{Lack of empirical data on environmental effectiveness}

Several studies state a general lack of empirical data on the environmental effectiveness of eco-labelling (OECD, 1997, p.8; EPA, 1994, p.19). Cadman and Dooley (2004) base their study on potentials of the EU-Flower in three different scenarios. They assume a 5,20 and 50\% market penetration of eco-labelled-products and substitution of 'average' products. Their results are calculated according to the most important environmental criteria and take various environmental parameters into account such as energy and $\mathrm{CO}_{2}$ savings, reduction of material, water and hazardous substances, and conclude considerable environmental benefits - if market penetration would increase as assumed. However, their estimations do not reflect 'real-world' benefits.

Locret and de Roo (2004) examined whether the European eco-label is ahead, in line or behind current (environmental and health) legislation in order to estimate their environmental effectiveness. According to them, in most cases the EU-Flower is ahead of legislation. This result is, of course, not very astonishing if we consider that the eco-label should signal environmental leadership of a certain share of products offered on the market and that criteria elaboration aims at going beyond existing legislation. 


\subsection{Indirect effects: impacts on policy and business}

The concept of indirect effects of eco-labelling is a relatively new one. Reinhard et al. (2001) stressed this point in an explicit manner as one of the first to do so. But so far, there is no uniform definition of the indirect effects of eco-labelling. However, - in our understanding - indirect environmental effects means environmentally positive impacts induced by eco-labelling schemes on surroundings in policy, business and society; outside of the effects on the applicant and participant in the European eco-label.

\subsubsection{Policy context: key role in Integrated Product Policy (IPP)}

With the emergence of the debate on IPP since the end of the 1990s (Rubik, 2006), voluntary eco-labelling schemes have come into focus. While in the past eco-labels have been considered predominantly as a 'stand-alone' tool aiming solely at coping with asymmetric information distribution among actors in the market, the IPP debate changed the 'image' of eco-labels.

Informative instruments such as eco-labels play a crucial role for integrating the product focus in existing policy instruments. Namely, third-party verification schemes (e.g., eco-labels like the EU-Flower, the German Blue Angel etc.) seem to have become core IPP instruments serving as benchmarks for environmentally sound products. Eco-labels are references for environmental excellence among products in the market; based on ecological life-cycle considerations. Thus, they allow fast and easy identification of environmentally 'good' products against 'bad' products; communicating a complex message in a simple way. That makes them a trustworthy policy tool for intelligent integration of instruments. There are several efforts to integrate the product focus by means of eco-label consideration:

- Integration in company-related process-oriented environmental policy: i.e., linking environmental management systems (e.g., EMAS) with eco-labels (Nielsen, 2002). On the Member state level, the Netherlands has been a frontrunner; experimenting already at the beginning of the 1990s with so-called Product-Oriented Environmental Management Systems (POEMS).

- Integration in economic instruments: i.e., reduction of Value-Added Tax (VAT) for eco-labelled products as proposed in the IPP Green Paper (CEC, 2001a). However, due to strong industry opposition, the Commission will not develop initiatives to apply reduced VAT rates to products bearing the European eco-label for the time being (CEC, 2003).

- Integration in regional structural policy: i.e., consideration of eco-labelled product for Community structural funds (Capozza et al., 2006).

- Integration in green public procurement policies: i.e., using eco-labelling criteria as technical specification (CEC, 2001b).

\subsubsection{Business context: information flow along the product chain}

In a way similar to the debate on integrating eco-labels within other policy instruments, there is a vision to elaborate an integrated information flow throughout the product life-cycle with several information tools linked with each other. 
Cadman and Dooley (2004, p.61f), for instance, calculated the application of the EU-Flower for the elaboration of ISO type II labels (green claims) and as a support for the elaboration for the so-called Environmental Product Declarations (EPDs) and presented some figures for cost reductions (potentials). As an important benefit they regard the application of EU-requirements by national schemes of Member States of the former EU-25, e.g., Austria, Nordic Swan, new EU-Member States, and estimated the indirect benefits on savings of $€ 1$ Mio and 21 man-years.

Rubik and Frankl (2005) recommend applying different environmental product information schemes, depending on the respective stakeholders, to use product categories to identify synergies between different environmental product information schemes, and to use mandatory comparative rather than voluntary selective environmental information schemes.

IEFE et al. (2006) asked for two other relationships. Application of the EU eco-label as criteria for product tests by third parties (e.g., consumer tests) was supported by the large majority ( $81 \%$ yes, $19 \%$ no). Stakeholders slightly disagreed about the contribution of the EU-Flower for the development of sector-oriented eco-labelling approaches.

\subsubsection{Indirect effects on non-labelled products and product development}

Many studies assume indirect effects on the whole product portfolio of companies through eco-labelling. However, these assumptions lack general empirical evidence.

Landmann $(1999$, p.47) estimates that eco-labels could indirectly force producers to produce/offer eco-labelled products. Nadai (1999) assumes that negotiation of eco-label criteria improves the environmental performance of a whole market sector. Cadman and Dooley (2004, p.59ff) suppose that eco-labels could be used by companies as benchmarks for their own products or as a target to improve their environmental performance. As a consequence, they assume that eco-label criteria could generate minimum environmental requirements applicable to all products of a product category on the market.

IEFE et al. (2006) asked stakeholders if the EU-eco-label had supported the informal development of a baseline requirement within branches. This indirect effect was slightly supported; claimed examples are beds/mattresses, textiles, paints and tourist accommodations. This confirms the literature (Nuij, 2004); according to which an eco-label is also used as an informal benchmark by non-participants. About half of the interviewed non-participating companies declared that they used the eco-label in all or some areas.

\subsubsection{Image and customer satisfaction}

As far as the relationship between the eco-label and the 'image' of the company on one hand and customer satisfaction on the other is concerned, most studies deal with a generic relationship between 'green products/firms' and the determinants of companies' competitiveness; highlighting how environmentally sound behaviour improves the image of companies as well as the customer satisfaction provided.

Indeed, there is evidence that consumers have a positive attitude towards companies marketing 'green', eco-labelled products. A 2003 survey on Italian consumers (Demoskopea, 2003) reports that, once informed about the nature and features of the EU Eco-Label, most interviewees affirmed that they will consider the latter as a variable in 
their purchasing decision process $(76 \%)$, or even prefer products with the Flower $(65 \%)$. The problem remains that very few consumer are aware of the EU Eco-Label.

Again, the evidence shows that 'green' firms (such as those selling eco-labelled products) will gain important competitive advantages (premium price, customer fidelity, 'glow effect', etc.). Indeed, the credibility of 'environmental friendliness' of companies is strongly supported by forms of external and independent certification, such as the EU Flower. Most of the evidence gathered on the issue supports the fact that product certification provides great credibility, hence improving the image and being a crucial factor for customer satisfaction.

This is in line with IEFE et al. (2006), as most of the interviewees expressed positive assessments of the overall effect of the EU Eco-Label registration on customer satisfaction (3.3 on a scale from 1 - not at all important to 5 - very important). However, we have to note that the credit given to the label in fostering higher customer satisfaction is counterbalanced by a scarce improvement of the relationship with all stakeholders, which actually obtained a low score (2.7).

But the 'in field' research also evidenced a further positive impact of the EU eco-label, as companies selling Flower-awarded products experience a sensible benefit (3.6) as regards the recognition as leader by competitors and other relevant actors.

The findings of the literature review are consistent with the concept that customer satisfaction is directly linked to the coupling of Eco-Labelling addressing the individual sphere of consumers (e.g., health, price etc.). Indeed, consumers nowadays develop a positive perception of those companies providing them with environmentally friendly products; provided that this is not counterbalanced by a lack in other dimensions that are still regarded as essential. We can mention, for instance, the Demoskopea (2003) survey, which shows how interviewees affirm that the quality $(49 \%)$ and the price $(47 \%)$ of labelled products have to be in line with those of 'traditional' products.

\subsubsection{Product innovation and eco-labelling}

As regards the relationship between environmental labels and innovation, evidence shows that there is a certain correlation, but it is not sure to what extent such innovation descends from the label itself (Dosi and Moretto, 2001). There are doubts that eco-labels spur spontaneous processes of environmental innovation. The survey carried out by Rennings et al. (2004) among German companies, examining the influences of Eco-Label on innovation patterns, points out that eco-labelling is used very little both by environmental product innovators and non-environmental product innovators.

Mattoo and Singh (1994) assert that there could even be negative impacts, such as the fact that an improvement of image 'hitting' the whole organisation will support an increase in investments, even in traditional, 'brown' technologies (complementarity's relationship). In other words, the benefits and resources deriving from an environmentally sound technology/product will display their effects on the organisation as a whole, supporting even those technologies that show little respect for environmental concerns.

The findings emerging from interviews seem to confirm that the European eco-label is not able to support innovation fundamentally. The average grade obtained by the "improved product innovation capability" option is a positive 3.1, but rates among the least important benefits gained by the European eco-label registration; none of the interviewees regarded it as 'very important'. 


\subsubsection{Other dimensions of competitiveness}

There is little evidence in literature as regards the relationship between other dimensions of competitiveness and the EU eco-label. The evidence elaborated by IEFE et al. (2006) provides a brighter picture of the competitiveness of the EU Flower, compared to that found in the literature review, and previously described.

When asked about the real benefits actually experienced by applying the scheme, most interviewees gave high ratings to many issues.

Despite this, even if a positive rating was obtained by 18 'benefits' out of the 23 listed in the corresponding question, we should point out that none obtained a 'very high' rating; 3.6 being the highest score achieved. This is consistent with the idea of the Eco-Label making a contribution to the competitiveness of firms, which is, however, pretty slight.

It is important to note that the main benefits sometimes come from the environmental field, and not the economic or competitive one. A better environmental performance (3.6) seems to be one of the brightest consequences of the Eco-Label registration, along with the recognition by competitors or other actors of the position of 'leader'. In Table 5, we report all of the benefits connected with the use of the Eco-Label, according to IEFE et al. (2006). The benefits that are more directly linked to a competitive advantage are in bold character.

Table 5 Benefits experienced by applying the European eco-label

\begin{tabular}{ll}
\hline Recognition as leader (and benchmark) by competitors or other & $\mathbf{3 . 6}$ \\
economic actors (trade associations, rating agency, etc.) & \\
Improved our environmental performance & 3.6 \\
To improve selection of raw materials & 3.5 \\
New customers (or contracts) or market shares acquired & $\mathbf{3 . 4}$ \\
Increased knowledge of a product's environmental impacts & 3.4 \\
Satisfy a specific request by (one or more of) our customers & $\mathbf{3 . 3}$ \\
Increased customer/consumer interest & $\mathbf{3 . 3}$ \\
Higher customer satisfaction & $\mathbf{3 . 3}$ \\
To improve waste management & 3.3 \\
Improved employee/management commitment to environmental performance & 3.3 \\
Keep up with our main competitors or with the other members of our & $\mathbf{3 . 2}$ \\
trade association & \\
Improved our international competitive capabilities & $\mathbf{3 . 2}$ \\
Improved our managerial capabilities in the environmental area & 3.2 \\
Improved product design and product development of all our products & 3.2 \\
To improve production methods and processes & 3.2 \\
Improved our national competitive capabilities & $\mathbf{3 . 1}$ \\
Identified 'hot spots' for improvements and external request & 3.1 \\
Improved product innovation capability & 3.1 \\
\hline
\end{tabular}

Original question: "What kinds of benefits do you actually experience by applying the EU Ecolabel? Rate your agreement with the following options; ratings go from 1 to 5: $5=$ Strongly agree $-4=$ agree $-3=$ neutral $-2=$ disagree $-1=$ strongly disagree." Source: IEFE et al. (2006, p.122f.) 


\section{Conclusions}

Eco-labelling plays a key role within environmental policy making. The change in policy patterns from regulative instruments to flexible and softer instruments stimulated the diffusion of eco-labelling as a tool of modern environmental policy. The emergence of IPP in the last ten years is a signal that the focus of policy making has expanded towards the environmental features of products and services. One prominent category of instruments applied in IPP is informative tools, and especially, eco-labelling. In recent years and especially after the international summit of Johannesburg in 2002, the focus of international environmental policy has been oriented towards Sustainable Consumption and Production (SCP) patterns. This has also integrated challenges connected to IPP whose importance may have decreased during this period. The political commitment to this approach was agreed at the Johannesburg-conference of 2002, and political take-up is progressing. At the moment, it seems that SCP has become a challenging issue within the sustainability debates and policies. International organisations, many countries and also the European Union have begun impressive activities in this area. It is expected that the European Union will agree to a SCP-action plan by 2007 demanding several activities be performed by Member States. It is expected that eco-labelling will play a prominent role in the foreseen measures. Besides the EU, individual Member States are active and once more the prominent role of eco-labels can be observed.

Altogether, eco-labelling has a considerable role in modern environmental policy. This statement is not restricted to Western economies. China and India have also introduced eco-labelling schemes, and so have most of the Asian 'Tiger' and 'Panther' countries. This observation is important for business: policy work in this area around the globe counts on eco-labelling!

Eco-labels could signal environmental leadership. They will be awarded to environmental benign products within a specific product category and serve as a benchmark. This indication of leadership is addressed towards business connected with the expectations that

- $\quad$ it is taken up by product development and considered as orientation for product innovation processes

- $\quad$ it is considered by marketing as an expression of 'market intelligence'

- $\quad$ it is applied by marketing for operative and strategic positioning of the products.

But eco-labels could also influence the product chain: Upstream suppliers get information about requests of their clients in order to fulfil the requirements of an eco-label and they might gain an impression of market development due to their missing a direct connection to the market of final products. Downstream commercial clients get information on the environmental features of products and services that they purchase.

But eco-labels are an informative decision support tool for consumers who are looking to reduce their information overload by considering an information chunk like the information delivered by an eco-label. This statement is not restricted to private consumers, but also to professional purchasers. Business, retailers or public procurers could take eco-labels into consideration.

Altogether eco-labelling could have a considerable influence on the market - both on supply and demand. Beside the visible and countable direct impacts such as the number 
of, and turnover with, eco-labelled products, we hinted to the importance of indirect impacts with which business not requiring the application of an eco-label could align their product development. As signals, eco-labels are warmly welcome and supported by policy. We believe that the future strategies in the above mentioned areas of IPP and SCP - both on the international and on national levels - will deepen the strategic high positioning of eco-labelling. An example introduced above is the prominent role of eco-labels as compliance proof for EuP. This supports the diffusion of eco-labels. The ongoing integration of informative instruments, the integration of environmental policy instruments and the integration of different policy areas will strengthen this development.

But if the spreading out continues, does this development really have a microeconomic 'counterpart'? Is it a self organised process that business takes up and embeds into its strategy? Currently, the judgement is ambivalent. A series of companies apply an eco-label, they are aware of the requirements, they make money. In several countries, consumers know an eco-label but, in general, its visibility and application is restricted. Empirical data seldom exist, and success stories are more anecdotal than real.

We think that market should be supported by several improvements of framework conditions.

First of all, the number of products groups must expand. It is still restricted to about 100 on the European market. For 15 years, we have had an internal market within the European Union. We have large markets in the USA, in China and in India. But what is missing is a closer cooperation between the different schemes. This is missing - astonishingly enough - within the European Union; not to speak globally. Business needs orientation and signals on societal targets; especially for environmental and social ones, of which at least the first could be transmitted by the requirements of an eco-label for the specific product groups. Therefore, more international cooperation and coordination is needed to 'harmonise' requirements. Some proposals have been presented by IEFE et al. (2006) in the context of the European Flower and the other national schemes within the European Union.

Secondly, a stronger and continuous support with regard to data transmission is needed. Business needs stronger information on the market for eco-labelled products. A monitoring system should be elaborated which collects data on the number and turnover of eco-labelled products. A databank on environmental impacts has to be implemented. Some promising approaches of LCA databases should expand and deliver reliable data in an appropriate format to product developers and designers. Business also needs more data on the average market. This might be a challenge addressed to statistical agencies, such as the European statistical agency (eurostat).

Third, business needs a stronger emphasis to incorporate and institutionalise environmental issues in the different departments. Eco-label issues should be not just up to an environmental or sustainability department, but be more broadly embedded. This experience is a central outcome of the history of the application of LCA in business (Frankl and Rubik, 2000). The integration of tools needs an integrated strategy and an incorporation into operative decision making.

Fourth, a series of proposals on how to link the eco-label with other environmental policy tools, how to change the structure and make them leaner, how to expand schemes with regard to sustainability have all been elaborated by us and reported within IEFE et al. (2006). The uptake of the most promising measures (namely better support of applicants, intensification of marketing and promotion, stronger linkages with green 
public procurement and fiscal incentives and a clear structure of the decision process) is needed.

Altogether, eco-labels could play a central role as benchmarks. They could indicate environmental leadership and act as an impulse for strategic long-term planning: The decades of the environment are in front of us. It is not an issue from the last century.

\section{References}

Baldo, G. (2001) LCA - Life Cycle Assessment, IPA Servizi editore, Milano.

Bennet, M. and James, P. (Eds.) (1999) The Green Bottom Line, Greenleaf, Sheffield.

Berchicci, L. and Bodewes, W. (2005) 'Bridging environmental issues with new product development', Business Strategy and the Environment, Vol. 14, No. 5, pp.272-285.

BEUC (The European consumers' organisation) (2002) Give more Power to the Flower, Press release PR 038/2002 of BEUC, Bruxelles.

Bouwer, M., de Jong, K., Jonk, M., Berman, T., Bersani, R., Lusser, H., Nissinen A., Parikka, K. and Szuppinger, P. (2005) Green Public Procurement in Europe 2005 - Status Overview, Report of the 'Take 5' Consortium for the European Commission - DG Environment, Brussels, http://ec.europa.eu/environment/gpp/pdf/report_facts.pdf - visit as of 27 January, 2007.

Cadman, J. and Dooley, P. (2004) The Direct and Indirect Benefits of the European Eco-label - Final Report, Study on behalf of DG Environment, London.

Capozza, I., Mautone, O. and Sorce, M.A. (2006) 'The implementation of integrated product policy in southern Italy: the role of community structural funds', in Scheer, D. and Rubik, F. (Eds.): Governance of Integrated Product Policy In Search of Sustainable Production and Consumption, Greenleaf, Sheffield, pp.243-257.

Carnimeo, G. and Iraldo, F. (2000) 'Nuove prospettive delle politiche ambientali comunitarie: la integrated product policy', Economia delle Fonti di Energia e dell'Ambiente, Vol. 2, No. 2, pp.85-120.

Commission of the European Communities (CEC) (2001a) Greenbook Integrated Product Policy, COM (2001) 68 final, Own publication, Brussels.

Commission of the European Communities (CEC) (2001b) Commission Interpretative Communication on the Community law Applicable to Public Procurement and the Possibilities for Integrating Environmental Considerations into Public Procurement (COM (20019 274 final), Own Publication, Brussels.

Commission of the European Communities (CEC) (2003) Communication from the Commission to the Council and the European Parliament. Integrated Product policy' - Building on Environmental Life-cycle Thinking (COM (2003) 302 final), Own publication, Brussels.

Cramer, J. (2000) 'Responsiveness of industry to eco-efficiency improvements in the product chain: the case of Akzo Nobel', Business Strategy and the Environment, Vol. 9, No. 1, pp.36-48.

Demoskopea, A. (2003) 'Monitor ecolucart', Proceedings of the Conference: 'Quale ruolo per la GDO?', Milan, 21 September, pp.27-92.

Dosi, C. and Moretto, M. (2001) 'Is eco-labelling a reliable environmental policy measure?', Environmental and Resource Economics, Vol. 18, No. 1, pp.113-127.

EHS Gestione (2006) Study on the Definition of an Eco-marketing Strategy, Report for the IZA - International Zinc Association and EGGA - European General Galvanisers Association, Brussels.

Environmental Protection Agency (EPA) (1994) Determinants of Effectiveness for Environmental Certification and Labeling Programs, Own Publication, Washington. 
Environmental Protection Agency (EPA) (1998) Environmental Labelling Issues, Policies and Practices Worldwide, Own Publication, Washington.

Foster, C. and Green, K. (2000) 'Greening the innovation process', Business Strategy and the Environment, Vol. 9, No. 5, pp.287-303.

Frankl, P. and Rubik, F. (2000) Life Cycle Assessment in Business and Industry: Adoption Patterns, Applications and Implications, Springer, Heidelberg.

Frey, M., Iraldo, F., Pratesi, C.A., de Clerq, M., Senesael, F. and Pots, T. (1998) Project for the Promotion and the Diffusion of the EU Eco-label in Italy and the Benelux, Report on behalf of DG Environment, Brussels.

Fuller, D.A. (1999) Sustainable Marketing. Managerial-ecological Issues, SAGE Publications, Thousand Oaks, London, New Delhi.

Gloria, T., Gloria, T., Saad, T., Breville, M. and O’Connell, M. (1995) 'Life-cycle assessment: a survey of current implementation', Total Quality Environmental Management, Vol. I, No. 4, pp.33-50.

IEFE et al. (2006) EVER: Evaluation of eco-label and EMAS for their Revision - Research findings, Final report to the European Commission - DG Environment, Brussels, www.europa.eu.int/comm/environment/emas.

Iraldo, F. (2000) 'La Grande Distribuzione Organizzata raccoglie la sfida ambientale', Largo Consumo, Vol. 22, No. 9, pp.67-70.

ISO (1999) Environmental Labels and Declarations - Self-declared Environmental Claims (Type II Environmental Labelling) (ISO 14021: 1999), Own Publication, Geneve.

ISO (2000) Environmental Labels and Declarations - Type I Environmental Labelling - Principles and Procedures (ISO 14024: 1999), Own Publication, Geneve.

ISO (2007) Environmental Labels and Declarations - Type III Environmental Declarations - Principles and Procedures (ISO 14025: 2007), Own Publication, Geneve.

Istituto di Economia e Politica dell'Energia e dell' Ambiente (IEFE) (2004) Rapporto sulla diffusione dell'Eco-Label Europeo in Italia, Research report of the University Bocconi, Milano.

Jordan, A., Wurzel, R., Zito, A. and Brückner, L. (2004) 'Consumer responsibility-taking and eco-labelling schemes in Europe', in Micheletti, M., Follesdal, A. and Stolle, D. (Eds.): Politics, Products and Markets: Exploring Political Consumerism Past and Present, Transaction Publishers, New Brunswick, London, pp.161-180.

Kvistgaard Consults (2005) Evaluation of the EU Flower Week - Campaign 2004 - Final Report, http://glwww.mst.dk/indu/pdf/Final\%20report\%20-\%20EU\%20Flower\%20evaluation. pdf - visit as of 13 January, 2007.

Landmann, U. (1999) Nationale Umweltzeichen im Zuge der Globalisierung von Wirtschafts-, Umwelt- und Sozialpolitik, PhD Theses, Berlin, internet, http://darwin.inf.fu-berlin.de/ 1999/22/ - visit as of 13 January, 2007.

Leitner, E., Stifter, R. and Tauchhammer, S. (2004) Development and Implementation of a Marketing and Communication Strategy for the European Eco-label on Tourist Accommodation Services, Final Report to DG Environment, Brussels, http://ec.europa.eu/ environment/ecolabel/pdf/market_study/tourismmktgreport_0704.pdf - visit as of 13 January, 2007.

Locret, M.P. and de Roo, C. (2004) The EU Eco-label - Less Hazardous Chemicals in Everyday Consumer Products, Study to EEB, Brussels, http://ec.europa.eu/environment/ecolabel/pdf/ studies/beucstudy2004_en.pdf - visit as of 13 January, 2007.

Mattoo, A. and Singh, H. (1994) 'Eco-labelling: policy-considerations', Kyklos, Vol. 47, No. 1, pp.53-65.

Miljømerking, S. (2005) Alle kjenner Svanen - noen kjenner Blomsten, Oslo, http://www. Eco-Label.no/cgi-bin/svanen/imaker?id=2417, visit as of 23 November, 2005. 
Nadai, A. (1999) 'Conditions for the development of product eco-label', European Environment, Vol. 9, No. 5, pp.202-211.

Neveling, S. (2000) Produktinnovation durch Umweltzeichen, Nomos, Baden-Baden.

Nielsen, B. (2002) Study on: Possible Interaction and Synergy between Environmental Management Systems and Ecolabels, Study on behalf of Danish Environmental Protection Agency, Copenhagen.

Nuij, R. (2004) Possible Synergies between the EU Eco-label and other Product Related Instruments and Tools, Background Paper for the consideration of the Policy Management Group of the European Union Eco-labelling Board, Brussels, http://ec. europa.eu/environment/ecolabel/pdf/work_plan/mgtgroups/policy/backgdpapersynergiespmg 300904.pdf - visit as of 25 January, 2007.

Organisation for Economic Co-operation and Development (OECD) (1997) Eco-labelling: Actual Effects of Selected Programmes, Own publication, Paris.

Pujari, D., Wright, G. and Peattie, K. (2003) 'Green and competitive - influences on environmental new product development performance', Journal of Business Research, Vol. 8, No. 56, pp.657-671.

Reinhard, Y. Naess, B., Cederlöf, M., Väisänen, P., Nielsen, C. and Skjenstad, T. (2001) Evaluation of the Environmental Effects of the Swan Eco-label - Final Analysis, Report to the Nordic Ministers, Stockholm, http://www.norden.org/pub/velfaerd/konsument/sk/ TN2001516.pdf - visit as of 26 January, 2007.

Rennings, K. Ziegler, A. and Rehfeld, K. (2004) Integrated Product Policy and Environmental Product Innovations: An Empirical Analysis, ZEW Discussion Papers, Mannheim.

Rousseau, C. (2004) Label écologique européen: quels impacts sur les choix de consommation?, CRIOC, Bruxelles.

Rubik, F. (2006) 'Policy profile: integrated product policy - between conceptual and instrumental approaches in Europe', European Environment, Vol. 16, No. 5, pp.307-320.

Rubik, F. and Frankl, P. (2005) The Future of Eco-labelling: Making Environmental Product Information Systems Effective, Greenleaf, London.

Scheer, D. (2006a) 'Environmental governance and integrated product policy', in Scheer, D. and Rubik, F. (Eds.) (2006) Governance of Integrated Product Policy in Search of Sustainable Production and Consumption, Greenleaf, Sheffield, pp.44-68.

Scheer, D. (2006b) Governance und Nachhaltigkeit, Discussion Paper Series of the IÖW 183/06, Berlin.

Schiesser, P. and Shinn, M. (2004) EEB Evaluation of the European Eco-label Criteria and Scheme, Study on behalf of the European Environmental Bureau, Brussels.

Sullivan, M.S. and Ehrenfeld, J.R. (1992) 'Reducing life-cycle environmental impact: an industry survey of emerging tools and programs', Total Quality Environmental Management, Winter, 1992-1993, pp.143-157.

Taloustutkimus, O. (2004a) EU-ympäristömerkin tunnettuus, Omnibus, Awareness of EU-Eco-Label in Finland, Omnibus, Study on behalf of SFS-Eco-Labelling 2/2004, Helsinki.

Taloustutkimus, O. (2004b) Pohjoismaisen ympäristömerkin tunnettuus, Omnibus, Awareness of Nordic Eco-Labelling in Finland, Study on behalf of SFS-Eco-Labelling 3/2004, Helsinki.

Tukker, A., Haag, E. and Eder, P. IPTS (2000) Eco-design: Strategies for Dissemination to SMEs, ECSC-EEC-EAEC - Report EUR 19740 EN, Brussels and Luxemburg.

Umweltbundesamt (UBA) (1990) Twenty Arguments Against the Environmental Label, Federal Environmental Agency, Berlin.

Yang, W. (1998) 'Eco-labelling: its role in promoting sustainable production and consumption', Paper for the International Symposium on Policy Instruments for Sustainable Consumption and Production: The Search for Effective Steering, Oslo. 